Praca poglądowa/Review paper

\title{
Przykłady zastowania automatycznego planowania leczenia w praktyce klinicznej zaprezentowane podczas konferencji estro 35
}

\author{
The exapmles of use of automated treatmet plan generation in \\ the clinical routine presented at the estro 35 conferencein modern \\ radiotherapy
}

\section{Maria Olmińska ${ }^{1}$}

${ }^{1}$ Zakład Fizyki Medycznej, Wielkopolskie Centrum Onkologii, Poznań, Polska

\section{Streszczenie}

Celem pracy jest przedstawienie przykładów zastosowania automatycznego planowania leczenia w praktyce klinicznej, zaprezentowanych podczas konferencji ESTRO 35 w Turynie.

\begin{abstract}
The aim of this paper is to underline the most important aspects of automated treatment plan generation in clinical routine. The described trends and some research problems were presented during ESTRO 35 conference in Turin.
\end{abstract}

Stowa kluczowe: automatyczne planowanie leczenia, RapidPlan, Erasmus-iCycle

Keywords: automatic treatment planning, RapidPlan, Erasmus-iCycle

Adres do korespondencji

Maria Olmińska

Zakład Fizyki Medycznej

Wielkopolskie Centrum Onkologii, ul. Garbary 15, 61-866 Poznań, Polska

Telefon. +4861885 o 522

e-mail: maria.olmińska@wco.pl 


\section{Wstęp}

Jednym z tematów będących przedmiotem konferencji ESTRO 35, która odbyła się w dniach od 29 kwietnia 2016 roku do 3 maja 2016 roku w Turynie, było zastosowanie automatycznego planowania leczenia w teleradioterapii. Wyróżnikiem zeszłorocznej konferencji była nie analiza aspektów teoretycznych procesu, a zaprezentowanie doświadczeń różnych ośrodków w wykorzystywaniu tego narzędzia w praktyce klinicznej. Przedstawiono 10 wystapień ustnych oraz 5 plakatów w tym m. in. badanie z Centrum Onkologii Humanitas (Włochy) oraz badanie międzynarodowe. Na przykładzie tych dwóch powyższych prac oparty został niniejszy artykuł.

Pierwsze pytanie jakie nasuwa się podczas analizy przedmiotowego tematu to przede wszystkim: jakie są motywy i cele stosowania automatycznego planowania leczenia. Niewątpliwie, jak sama nazwa tej techniki planowania wskazuje, automatyzuje ona, a co z tym związane ułatwia cały proces. Poprawia wydajności pracy w pracowniach fizyki, dzięki skróceniu czasu planowania leczenia. Dzięki przechowywaniu w usystematyzowany sposób danych dotyczących poprzednich planów leczenia, metoda ta pozwala na doskonalenie procesu w oparciu o wcześniejsze doświadczenia i umożliwia dzielenie się uzyskaną uprzednio wiedzą - również z ośrodkami oddalonymi o wiele kilometrów. Daje to możliwość, także mniej doświadczonym fizykom, tworzenia planów wysokiej jakości, z uwagi na marginalizację znaczenia wpływu czynnika ludzkiego [1-5].

\section{- RapidPlan}

Istnieje szereg zróżnicowanych systemów do automatycznego planowania leczenia. We włoskim ośrodku Humanitas używane jest rozwiązanie firmy Varian o nazwie RapidPlan. Ideą jego działania jest tworzenie modeli do automatycznego planowania leczenia. Powstają one na podstawie wielu wysokojakościowych planów, a dokładnie informacji dozymetrycznych i geometrycznych wprowadzonych do systemu. Dla nowotworzonych planów model szacuje zakres histogramu dla narządów krytycznych, a dolna granica tego zakresu stanowi jego cele optymalizacyjne używane podczas procesu optymalizacji nowego planu. Przed wdrożeniem modelu do praktyki klinicznej weryfikuje się poprawność jego działania [5-6].

Jednym z przykładów zastosowania tej metody planowania jest model dla chorych z nowotworami głowy i szyi. Zbudowany został on na podstawie planów 83 chorych z nowotworem złośliwym. Każdy otrzymał dawkę całkowitą 70 Gy. Narządami krytycznymi w tych przypadkach klinicznych były: rdzeń kręgowy, pień mózgu, przyusznice, jama ustna, krtań, tarczyca, żuchwa, ślinianki, oczy, nerwy wzrokowe i chiazma. Plany zostały utworzone w technice łukowej (VMAT, ang. Volumetric Arc Therapy) z 2 do 4 łuków o energii 6 MV. Ustalono parametry, które muszą spełniać objętości tarczowe (PTV, ang. PlannigTarget Volume) i narządy krytyczne. Dla przykładu dawka maksymalna dla PTV nie mogła przekroczyć $110 \%$ dawki zadanej, a dla rdzenia kręgowego 45 Gy. Fizyk planujący utworzył manualnie plany dla 10 kolejnych chorych w taki sposób, aby otrzymać klinicznie akceptowalny plan, tj. spełniający wszystkie określone wytyczne. Dodatkowo fizyk planujący, przy pomocy narzędzia RapidPlan, używając jedynie utworzonego w nim wcześniej modelu stworzył plany dla tej samej grupy pacjentów. Następnie plany te zostały ze sobą zestawione i porównane. W konsekwencji czego otrzymano poniższe wyniki, przedstawione w tabeli 1:

Tabela 1. Procentowa różnica pomiędzy planami utworzonymi w systemie RapidPlan a tymi zaplanowanymi manualnie. Kolorem zaznaczono wartości, dla których lepsze były plany utworzone automatycznie [6].

Struktura

\section{Parametr}

Średnia różnica pomiędzy RapidPlanem a planem manualnym [\%]
V95\% [\%]
$-0,2 \pm 0,6$

PTV
V105\% [\%]
$-0,03 \pm 0,04$ 


\begin{tabular}{ccc}
\hline & Max [Gy] & $-15,3 \pm 16,5$ \\
\cline { 2 - 3 } Rdzeń kręgowy & Mean [Gy] & $-9,5 \pm 29,1$ \\
\hline Pień mózgu & Max [Gy] & $-23,5 \pm 10,7$ \\
\cline { 2 - 3 } & Mean [Gy] & $-35,9 \pm 1,1$ \\
\hline Ślinianki & Mean [Gy] & $-5,1 \pm 3,5$ \\
\hline Jama ustna & Mean [Gy] & $-9,2 \pm 5,5$ \\
\hline Krtań & Mean [Gy] & $-20,4 \pm 12,7$ \\
\hline Żuchwa & Mean [Gy] & $-0,7 \pm 3,5$
\end{tabular}

Dla PTV różnice nie były statystycznie istotne, natomiast dla narządów krytycznych plany utworzone w systemie RapidPlan okazały się bezpieczniejsze dla zdrowia pacjentów. Dzięki zastosowaniu narzędzia do automatycznego planowania leczenia udało się zauważalnie zredukować dawkę dla w/w narządów.

Użycie Rapidplanu pozwoliło skrócić czas planowania z 75-90 minut do 25 minut, między innymi dlatego, że w programie tym nie trzeba tworzyć dodatkowych struktur do planowania. Jak twierdzą jego użytkownicy, oprogramowanie to jest łatwe w użyciu. Przewagą tego rozwiązania jest nie tylko automatyzacja procesu planowania, ale przede wszystkim „knowledge based planning” - możliwość dzielenia się wiedzą i doświadczeniem [6].

\section{- Erasmus-iCycle}

Badanie międzynarodowe zostało sfinansowane przez spółkę Elekta AB, a brało w nim udział 6 ośrodków: 1) Instytut Onkologii Erasmus MC, Holandia, 2) Elekta AB, Szwecja, 3) Azienda Ospedaliero-Universitaria Carregi, Włochy, 4) Wiedeński Uniwersytet Medyczny, Austria, 5) Szpital St. James, Wielka Brytania oraz 6) Uniwersytet Medyczny w Mannheim, Niemcy. Narzędziem, którym posługiwali się uczestnicy było oprogramowanie Erasmus-iCycle, oparte na systemie Monaco. W Rotterdamie, gdzie mieści się ośrodek Erasmus, jest ono rutynowo używane do planowania leczenia chorych z nowotworami: prostaty, głowy i szyi oraz płuc [8].

Badanie to zostało przeprowadzone dla chorych z rakiem prostaty. Wszystkie biorące w nim udział ośrodki stosowały ten sam protokół. Zawierał on plany, utworzone w technice łukowej dla 30 niedawno leczonych pacjentów. $10 \mathrm{z}$ nich użyto do konfiguracji systemu do automatycznego planowania, aby w następnym kroku na ich podstawie wygenerować automatycznie pozostałe plany. Utworzone zostały „wishlisty” (tabela 2), zawierające wszystkie wytyczne jakie mają spełniać struktury. Dla wszystkich powyżej wspomnianych ośrodków leczenia kluczowy był PTV, a następnie odbytnica i pęcherz. 
Tabela 2. Przykładowy „wishlist” dla prostaty [7].

\section{Wytyczne dla struktur}

Struktura

PTV
Typ

Maks
Limit dawki

104\% dawki zadanej

\section{Ważność}

\begin{tabular}{cccc}
\hline 1 & Odbytnica & Średnia & 33\% dawki zadanej \\
\hline 2 & Pęcherz & Średnia & $60 \%$ dawki zadanej \\
\hline 3 & Główki kości udowych & Średnia & $25 \%$ dawki zadanej
\end{tabular}

Porównanie planów utworzonych automatycznie, z tymi utworzonymi manualnie składało się z dwóch części: porównania na podstawie histogramów dawka-objętość oraz oceny przez lekarza specjalistę.

Z pierwszej części otrzymano wyniki przedstawione na wykresach (ryc. 2):



0

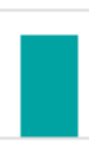

$-4$

$-3$

$-2$
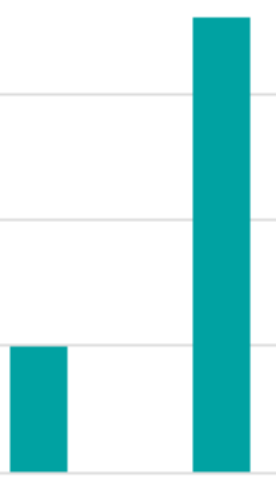

$-1$

0

1

2

3

4 
14



20



Rycina 2. Porównanie automatycznych planów i tych utworzonych manualnie na podstawie analizy 3 parametrów: objętości PTV pokrytej dawką 95\% , średniej dawki w odbytnicy i pęcherzu moczowym [Gy]. Na osi rzędnych o oznacza brak różnic, wartości dodatnie - korzystniejsze plany automatyczne; wartości ujemne - korzystniejsze plany 
Powyższe wykresy ukazują stopień zróżnicowania planów wykonanych dwoma sposobami. Ich analiza pozwala zauważyć, że dla objętości tarczowej czyli PTV różnice pomiędzy planami są niewielkie maksymalnie 4\%. Natomiast dla parametrów: średnia dawka w odbytnicy i pęcherzu różnice wyrażone w grejach są większe (aż do 12 Gy), występują dla większej liczbie planów. W tym przypadku zdecydowanie korzystniej wypadają plany utworzone automatycznie.

Ocena przez lekarza polegała na wizualnej ocenie jakości planów. Określał on, który plan jest jego zdaniem lepszy: automatyczny czy utworzony manualnie oraz w jakim stopniu (niski czy wysoki współczynnik). Wyniki przedstawia wykres (ryc. 3):

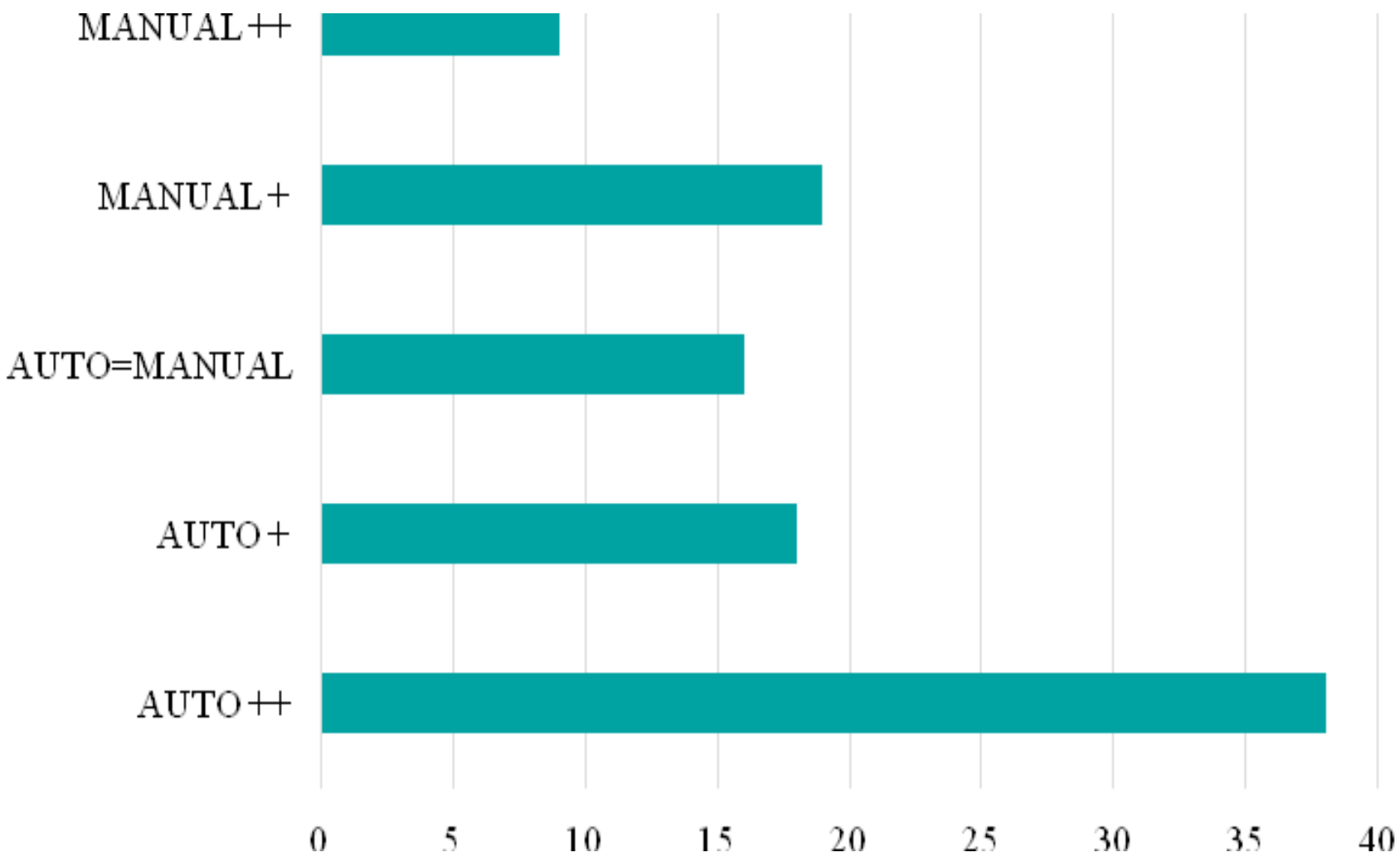

Rycina 3. Wykres przedstawiający wyniki porównania automatycznych planów z utworzonymi manualnie przez lekarza. Znak równości oznacza brak różnic pomiędzy planami, jeden plus oznacza niewielki stopień różnicy, dwa plusy - duży [\%] [7]

W 38\% przypadków plany automatyczne okazały się lepsze od tych planowanych manualnie z wysokim współczynnikiem istotności, a jedynie w 9\% przypadków plany utworzone manualnie przewyższały jakością plany automatyczne. W 72\% przypadków jakość planu automatycznego była lepsza, bądź zbliżona do planu manualnego.

Obie metody porównania planów wykazały, że lepsze okazały się plany utworzone automatycznie [7, 8].

Każde z zaprezentowanych podczas konferencji ESTRO 35 wystąpień dotyczących automatycznego planowania leczenia wykazywało, że jest to rozwiązanie ułatwiające codzienną pracę fizyków medycznych. Narzędzia zautomatyzowane pozwalają obecnie na planowanie w różnych lokalizacjach, zarówno w technice IMRT jak i VMAT, a trwające prace nad systemem do automatycznego planowania leczenia dla CyberKnife [8] są na wysokim stopniu zaawansowania. Automatyczne planowanie stanowi istotne uproszczenie oraz skraca czas niezbędny dla wykonania planu, szczególnie w przypadku planowania adaptacyjnego [9]. Rozkłady dawek otrzymane dla PTV nie odbiegają od tych otrzymanych w planach utworzonych w systemach do tradycyjnego planowania, a w narządach krytycznych dawka zostaje zauważalnie zredukowana. Rozwiązanie takie uniezależnia jakość wytworzonego planu od doświadczenia fizyka planującego. Ponadto jest łatwe w użyciu, a ośrodki używające go w praktyce klinicznej potwierdzają, że sprawdza się w codziennej pracy. 


\section{Konflikt interesu / Conflict of interest}

Nie występuje / None

\section{Finansowanie / Financial support}

Praca była finansowana z grantu Wielkopolskiego Centrum Onkologii w Poznaniu. / Thiswork was supported by the Greater Poland Cancer Centre.

\section{Etyka / Ethics}

Treści przedstawione w artykule są zgodne z zasadami Deklaracji Helsińskiej, dyrektywami EU oraz ujednoliconymi wymaganiami dla czasopism biomedycznych

\section{Piśmiennictwo / References}

[1] J. A. Moore, K. Evans, W. Yang, J. Herman and T. McNutt, Automatic treatment planning implementation using a database of previously treated patients; Journal of Physics: Conference Series 489 (2014) 012054;

[2] Y. Wang, S. Breedveld, B. Heijmen and S. F. Petit, Evaluation of plan quality assurance models for prostate cancer patients based on fully automatically generated Pareto-optimal treatment plans, Physics in Medicine and Biology, Volume 61, Number 11, 2016;

[3] Y. He, L. Zhang, J. Xiao, B. Duan, Feasibility of Automatic Treatment Planning in Intensity-modulated Radiotherapy of Nasopharyngeal Carcinoma, Sheng Wu YiXue Gong Cheng Xue Za Zhi. 2015 Dec;32(6):1288-93;

[4] P. W. Voet, M. L. Dirkx, S. Breedveld, D. Fransen, P. C. Levendag, B. J. Heijmen, Toward fully automated multi criterial plan generation: a prospective clinical study, Int J RadiatOncolBiolPhys. 2013 Mar 1;85(3):866-72;

[5] J.Krayenbueh, I.Norton, G.Studer and M. Guckenberger, Evaluation of an automated knowledge based treatment planning system for head and neck, RadiationOncology (2015) 10:226;

[6] A. Fogliata, Automated treatment plan generation - the Milan experience, materiały zjazdowe konferencji ESTRO 35, Turyn, 29.04-3.05.2016;

[7] B. Heijmen, Fully automated VMAT plan generation - an international multi-insitutional validation study, materiały zjazdowe konferencji ESTRO 35, Turyn, 29.04-3.05.2016;

[8] M. Dirkx, Fully automated treatment plan generation using Erasmus-iCycle - the Rotterdam experience, materiały zjazdowe konferencji ESTRO 35, Turyn, 29.04-3.05.2016;

[9] N. Li, M. Zarepisheh, A. Uribe-Sanchez, K. Moore, Z. Tian, X. Zhen, Y. J. Graves, Q. Gautier, L. Mell, L. Zhou, X. Jia, S. Jiang, Automatic treatment plan re-optimization for adaptive radiotherapy guided with the initial plan DVHs, PhysMed Biol. 2013 Dec 21;58(24):8725-38; 